\title{
Kronik hepatit b tedavisinde HBsAg ve M30 antijen titre takibinin klinik yararı
}

\section{Clinical utility of HBsAg and M30 antigen titer follow-up in chronic hepatitis B treatment}

\author{
Zeynep Dündar Ök, Mustafa Çelik, İsmail Hakkı Akbudak, Yüksel Güleryüzlü, Halil Yılmaz, Mustafa \\ Yılmaz
}

Gönderilme tarihi:18.11.2020

Kabul tarihi:18.01.2021

Öz

Amaç: Antiviral tedavi öncesi ve sonrası serum HBsAg ve cccDNA düzeyleri ve bu değerlerdeki düşüş oranları arasında pozitif ilişki olduğu bilinmektedir. Serolojik HbsAg seviyesi de cccDNA ile ilişkilendirilmiştir ve serolojik $\mathrm{HbsAg}$, enfekte olmuş hücreleri teşhis etmek için cccDNA'nın yerini alan bir biyobelirteç olarak kabul edilmiştir. M30 antijeni, apoptoz sırasında kaspaz proteinleri tarafından parçalanan CK 18 seviyelerini tespit etmek için kullanılır. Ayrıca KHB hastalığında, apopitoz belirteci olan M30 antijen düzeyleri ile karaciğer hasarı arasında ilişki olduğu gösterilmiştir. Bu çalışmada KHB enfeksiyonu'nun şiddeti ve nucleoz (t)ide analoğu (NA) tedavisine klinik yanıtının değerlendirilmesinde $\mathrm{HbsAg}$ ve M30 antijen titre takibinin yararını saptamayı amaçladık.

Gereç ve yöntem: Çalışmaya KHB enfeksiyonuna yönelik oral antiviral tedavi verilen 60 hasta dahil edildi. Tüm hastalarda tedavi başlangıcında saptanan AST, ALT, HBVDNA, HAİ, fibrozis ile HbsAg ve M30 antijen düzeyleri arasındaki korelasyon değerlendirildi. Tedavi başlangıcı ve tedavinin 6. ayında saptanan AST, ALT, HBVDNA, HbsAg ve M30 antijen düzeyleri karşılaştırıldı. Tedavi ile bu değerlerde saptanan düşüş oranları değerlendirildi. Ayrıca hastalar aldıkları tedaviye göre Lamivudin ve Tenofovir alanlar olarak iki gruba ayrıldı. İki grup tedavi ile AST, ALT, HBVDNA, HbsAg ve M30 antijen düzeylerindeki düşüş oranları açısından karşılaştırıldı. HbsAg ve M30 antijen seviyelerinin tedavi sonrası azalma oranı açısından iki grup da karşılaştırıldı.

Bulgular: Tedavi başlangıcında saptanan AST, ALT, HBVDNA düzeyleri ile HbsAg ve M30 antijen arasında pozitif korelasyon saptandı $(p<0,001)$. HAİ, Fibrozis dereceleri ile HbsAg arasında anlamlı ilişki saptanmazken $(p>0,05)$, HAl, Fibrozis dereceleri ile M30 antijen düzeyleri arasında pozitif korelasyon saptandı $(p<0,01)$. Tedavi verilen tüm hastalarda tedavinin 6. ayında saptanan AST, ALT, HBVDNA, HbsAg ve M30 antijen düzeylerinde, tedavi başlangıcına göre istatistiksel olarak anlamlı azalma olduğu görüldü $(p<0,001)$. Lamivudin ve Tenofovir grupları arasında HBVDNA düzeylerindeki düşüş oranları açısından anlamlı fark saptanmadı $(p>0,05)$. Bununla birlikte tedavi ile HbsAg ve M30 antigen düzeylerindeki düşüş oranları tenofovir grubunda lamivudin grubuna göre istatistiksel olarak anlamlı düzeyde daha yüksek saptandı $(p<0,001)$.

Sonuç: HbsAg ve M30 antijen düzeyi ölçümü KHB enfeksiyonu'nun şiddetinin ve tedavi etkinliğinin değerlendirilmesinde kullanılabilir. Tenofovir ile HbsAg ve M30 antijen düzeylerinde düşüşün lamivudin grubuna göre daha belirgin olması, bize KHB enfeksiyonunun en etkin ilaç seçeneği ile tedavisinin hücre ölümü-apoptozisin önüne geçilmesinde etkili olacağını gösterdi. Bu sebeple sadece ALT ve HBVDNA sonuçlarının takibine göre düşük direç bariyeri olan oral antivirallerin kullanımında ısrar edilmesinin yanlış olduğu kanaatindeyiz.

Anahtar kelimeler: Hepatit B enfeksiyonu, M30 antijen, HBsAg, nükleoz(t)id analogları, oral antiviral tedavi.

Dündar Ök Z, Çelik Ç, Akbudak İH, Güleryüzlü Y, Yılmaz H, Yılmaz M. Kronik hepatit b tedavisinde HBsAg ve M30 antijen titre takibinin klinik yararı. Pam Tıp Derg 2021;14:380-387.

\begin{abstract}
Purpose: Positive correlation has been detected between pretreatment and posttreatment serologic levels and amount of decrease of $\mathrm{HbsAg}$ and cccDNA. Serologic HbsAg level has also been correlated with cccDNA, and serologic $\mathrm{HbsAg}$ has been accepted to be a biomarker replacing cccDNA to diagnose infected cells. M30 antigen is used to detect CK 18 levels that are disintegrated by caspase proteins during apoptosis. As an indicator of apoptosis, M30 levels show liver injury in chronic Hepatitis B infection. In this study, we aimed to evaluate clinical efficacy of measurement of $\mathrm{HbsAg}$ and M30 titrated antigen levels for response to treatment of chronic Hepatitis B infection during follow-up.
\end{abstract}

Zeynep Dündar Ök, Uzm. Dr. Devizli Serverdazi Devlet Hastanesi, Dahiliye Polikliniği, Denizli, Türkiye, e-posta: zynpdundar@gmail.com (https://orcid.org/0000-0003-0925-2098) (Sorumlu Yazar)

Mustafa Çelik, Doç. Dr. Pamukkale Üniversitesi Tıp Fakültesi İç Hastalıkları Anabilim Dalı, Gastroentroloji Bilim Dalı, Denizli, Türkiye, e-posta: mustafa.dr29@hotmail.com (https://orcid.org/0000-0001-8175-2324)

İsmail Hakkı Akbudak, Dr. Öğr. Üye. Pamukkale Üniversitesi Tıp Fakültesi İç Hastalıkları Anabilim Dalı, Yoğun Bakım Bilim Dalı, Denizli, Türkiye, e-posta: ishakbudak@gmail.com (https://orcid.org/0000-0002-3716-9243)

Yüksel Güleryüzlü, Uzm. Dr. Kartal Lütfi Kırdar Eğitim ve Araştırma Hastanesi, İç Hastalıkları/Gastroentroloji Kliniği, İstanbul, Türkiye, e-posta: yukselguleryuzlu@hotmail.com (https://orcid.org/0000-0002-2522-1550)

Halil Yılmaz, Arş. Gör. Pamukkale Üniversitesi Tıp Fakültesi İç Hastalıkları Anabilim Dalı, Gastroentroloji Bilim Dalı, Denizli, Türkiye, e-posta: drhalil48@gmail.com (https://orcid.org/0000-0002-3191-2171)

Mustafa Yılmaz, Prof. Dr. Pamukkale Üniversitesi Tıp Fakültesi İç Hastalıkları Anabilim Dalı, Gastroentroloji Bilim Dalı, Denizli, Türkiye, e-posta: kmustyil@yahoo.com (https://orcid.org/0000-0003-4541-172X) 
Materials and methods: Sixty patients receiving oral antiviral therapy for chronic Hepatitis B infection were included in the study. Correlation in between before treatment antigen levels of AST, ALT, HBVDNA, HAI, fibrosiswith $\mathrm{HbsAg}$ and $\mathrm{M} 30$ were evaluated in all patients. Before treatment and at sixth of month of treatment antigen level results of AST, ALT, HBVDNA, HbsAg and M30 were compared. Detected decrement levels following treatment were evaluated. In addition, patients were grouped in two according to medicine received by the patients as Lavumidin and Tenofovir. Two groups were compared concerning age, sex, pretreatment antigen levels of AST, ALT, HBVDNA, HAI, Fibrosis, HbsAg and M30. Two groups were also compared concerning posttreatment decrement ratio of antigen levels of $\mathrm{HbsAg}$ and $\mathrm{M} 30$.

Results: Positive correlation was detected between levels of AST, ALT, HBVDNA and HbsAg and M30 antigens at pretreatment period measurements $(p<0.001)$. While no significant correlation was detected between $\mathrm{HAl}$, degree of Fibrosis and HbsAg ( $p>0.05)$, positive correlation was detected between HAl, degree of Fibrosis and m30 antigen levels $(p<0.01)$. Statistically significant decrements of antigen levels of AST, ALT, HBVDNA, HbsAg and $\mathrm{m} 30$ were detected at posttreatment sixth month compared to pretreatment levels in all treated patients $(p<0.001)$. There was no statistically significant difference between Lamivudin ve Tenofovir groups concerning decrement ratio of HBVDNA levels ( $p>0.05)$. However, the amount of decrease in antigen levels of $\mathrm{HbsAg}$ and m30 was statistically significantly more in Tenofovir group than Lamivudin group $(p<0.001)$.

Conclusion: Antigen level measurements of $\mathrm{HbsAg}$ and M30 can be used to detect severity of chronic hepatitis $B$ infection and to evaluate effectiveness of the treatment. Significant decrease of HbsAg and M30 antigen levels in Tenofovir group in contrast to Lamivudin group showed us that treatment of chronic Hepatitis B infection with the most potent medicine can be effective to avoid cell death-apoptosis. For this reason, we propose that insisting on usage of oral antivirals with low resistance barrier just by observing ALT and HBVDNA results is inadvisable.

Key words: Hepatitis B infection, M30 antigen, $\mathrm{HbsAg}$, oral antiviral treatment.

Dundar Ok Z, Celik C, Akbudak IH, Guleryuzlu Y, Yilmaz H, Yilmaz M. Clinical utility of HBsAg and M30 antigen titer follow-up in chronic hepatitis B treatment. Pam Med J 2021;14:380-387.

\section{Giriş}

Her yıl yaklaşık 1 milyon kişi HBV ile ilgili komplikasyonlardan (dekompanse siroz veya hepatosellüler kanser) kaybedilmektedir [1, 2]. Kronik Hepatit B (KHB) enfeksiyonu tedavisinden beklenen en optimal sonuç, tedavinin güvenle kesilebileceği tek durum olan HbsAg kaybıdır, ancak bu hedefe çok nadir ulaşılabilmektedir [3, 4].

Kovalent kapalı sirküler DNA (cccDNA) viral persistansın önemli bir göstergesidir ve antiviral tedavi sonrası cccDNA düzeylerinde azalmanın kalıcı virolojik yanıt ile ilişkili olduğu bildirilmiştir $[5,6]$. Serum HbsAg düzeyi cccDNA ile ilişkilidir ve enfekte hücrelerin tespitinde cccDNA'nın yerine kullanılabilecek bir markır olarak kabul edilmektedir [7, 8]. HBeAg negatif KHB ve Delta ajanlı KHB enfeksiyonu'nun interferon ve oral antiviral tedaviye yanıtının monitörizasyonununda $\mathrm{HbsAg}$ titre ölçümünün faydalı olabileceği bildirilmiştir $[9,10]$.

Tüm hepatit türlerinde inflamatuvar olay nekroz ve apopitozu içeren farklı mekanizmalar ile hepatosit ölümüne sebep olur [11-13]. KHB enfeksiyonu hepatik nekroinflamasyon yolu ile progresif karaciğer hastalığına sebep olabilen önemli bir faktördür [14-16]. Apopitoz belirteci olan M30 antijen düzeylerinin kronik hepatit C hastalığında fibrotik karaciğer hasarı ile ilişkisi gösterilmiştir [17]. Ayrıca serum M30 antijen seviyesinin KHB enfeksiyonunda apoptotik aktiviteyi gösterdiği rapor edilmiştir [18].

Günümüzde KHB tedavisinde direnç bariyeri yüksek ve düşük NA kullanılmaktadır ve tedavi takibi alanin aminotransferaz (ALT) ve HBVDNA düzeyleri ölçülerek yapılmaktadır. Ancak bunların takipteki yeterliliği tartışmalıdır. Örneğin serum ALT düzeyleri genellikle klinik rutinde karaciğer inflamasyonunda belirteç olarak kullanılır, ancak apoptoz ile gerceklesen hücre ölümünde $A L T$ düzeylerinin yeterli bilgi vermediği gösterilmiştir [15].

$\mathrm{Bu}$ çalışmada, KHB enfeksiyonunun şiddetinin ve NA ile tedavisinin etkinliğinin değerlendirilmesinde, HbsAg ve M30 antijen titre ölçümünün klinik yararını göstermeyi amaçladık. $\mathrm{HbsAg}$ ve M30 antijen düzeylerindeki değişimin, tedavi yanıtının değerlendirilmesi ve hastalığa en uygun tedavinin seçimi konusunda faydalı bilgiler sağlayabileceğini düşünüyoruz.

\section{Gereç ve yöntem}

Çalışmaya Hepatoloji polikliniğine başvuran ve AntiHbe (+) KHB enfeksiyonu ön tanısı ile karaciğer biyopsisi yapılan, sonrasında oral antiviral tedavi (Tenofovir veya Lamivudin) 
başlanması planlanan hastalar dahil edildi. Çalışmaya alınmadan önce tedavi kararı verilmiş olan, 32 lamivudin ve 31 tenofovir tedavisi planlanan toplam 63 hasta değerlendirmeye alındı. AntiHbe (+) KHB hastaları American Association for the Study of Liver Diseases tarafından yayınlanan guideline kullanılarak tanımlandı [19]. Hepatit C, delta hepatiti veya HIV koenfeksiyonu olan hastalar, alkol kullanımı (>40 gr/gün) olan hastalar, bilinen malignite öyküsü olan hastalar çalışmaya dahil edilmedi.

Hastaların tedavi öncesi yapılan tetkiklerinde saptanan aspartat aminotransferaz (AST), (ALT), HBV DNA düzeyleri, ayrıca tedavi öncesi karaciğer biyopsisinde saptanan hepatik aktivite indeksi (HAI) ve fibrozis düzeyleri kaydedildi.

Hastalar takibe alındı ve tedavinin altıncı ayında saptanan AST, ALT, HBVDNA düzeyleri kaydedildi. Tüm hastalardan tedavi başlangıcı ve tedavinin altıncı ayında kan alındı ve hastalardan alınan serum örnekleri santrifüj edildikten sonra -70 derecede saklandı. Çalışma sonunda alınan serum örneklerinden $\mathrm{HbsAg}$ ve M30 antijen düzeyleri çalışıldı.

Tüm hastalarda tedavi başlangıcında saptanan AST, ALT, HBVDNA, HAI, fibrozis ile $\mathrm{HbsAg}$ ve M30 antijen düzeyleri arasındaki korelasyon ilişkisi değerlendirildi. Daha sonra hastaların tedavi başlangıcı ve tedavinin 6 . ayında saptanan AST, ALT, HBVDNA, HbsAg ve M30 antijen düzeyleri karşılaştırıldı. Tedavi ile bu değerlerde saptanan düşüş oranları değerlendirildi.

Ayrıca hastalar aldıkları tedaviye göre Lamivudin ve Tenofovir alanlar olarak iki gruba ayrıldı. İki grup tedavi tedavi öncesi ve sonrası saptanan AST, ALT, HBVDNA HbsAg ve M30 antijen düzeylerindeki düşüş oranları açısından karşılaştırıldı.

Çalışma prospektif olarak yapıldı ve her hastadan bilgilendirilmiş onam formları alındı. Çalışma protokolü, Pamukkale Üniversitesi Tıp Fakültesi Girişimsel Olmayan Klinik Araştırma Etik Komitesi tarafından onaylandı

\section{Kantitatif serum HbsAg düzeyi ölçümü}

Serum HbsAg ölçümü için tüm örneklerden $10 \mathrm{ml}$ venöz kan alındı. Biyokimya tüplerine alınan kanlar hızla laboratuvara gönderildi. Ardından 5000 devir hızında 3 dakika santrifüj edildi ve serumları 2-3 kısım halinde eppendorf tüplerine ayrıldı. Örnekler analiz gününe kadar -70 derecede derin dondurucuda saklandı. Tüm örnekler tek seferde çalışıldı.

HbsAg (Dia.Pro, İtalya) ile yapılan çalışmada öncelikle toplanan bütün örnekler ve kit oda sıcaklığına getirildi. Kullanılan ELISA yöntemi, "fourth generation enzyme "immunoassay" prensibine dayanmaktadır. Çalışmada kitin standart ve kimyasalları hazırlandıktan sonra plakta bulunan kuyucuklara standart ve örnekler konuldu ve $100 \mu \mathrm{l}$. enzim konjugat eklendi. Ardından 2 saat $37^{\circ} \mathrm{C}$ 'de inkübasyon sağlandı. Konjugatın eklenmesinden sonra bütün plaklar wash buffer ile 4-5 kez yıkandı. Bütün plaklara, $200 \mu \mathrm{l}$. kromojen substrat eklendi. 30 dakika $18-24^{\circ} \mathrm{C}$ 'de inkübasyon sağlandı. $100 \mu$ l. sülfirik asit her bir kuyucuğa eklenerek örneklerin renklenmesi sağlandı. Renk oluşumu gözlendikten sonra 450 nanometrede (nm.) Kayto RT-2100c Microplate reader ELISA cihazı ile kuyucukların absorbans değerleri okundu ve sonuçların çıktısıalındı. Bulunan serum absorbans değerleri kullanılarak konsantrasyonlar hesaplandı. Bulunan değerler HbsAg için IU/L şeklindedir.

\section{Serum M30 antijen düzeyi ölçümü}

Serum M30 antigen düzeyleri Human Cytokeratin 18-M30 (AP-M30 Bioassay Technology Laboratuary) kiti kullanılarak enzim bağlı immunosorbent deneyi (ELISA) yöntemi ile ölçüldü. M30 antijen titreleri 5 IU/L-900 IU/L ölçüm aralığında verildi.

AP-M30 için spesifik antikorlar plakalara yerleştirildi. Kitin standart ve kimyasalları hazırlandıktan sonra plakta bulunan kuyucuklara standart ve örnekler konuldu. Mevcut AP-M30 ile antikorlar bağlandı. Kalan bağlanmamış örnekler çıkarıldıktan sonra APM30 için spesifik biyotin ile konjuge edilmiş antikor eklendi. Yıkamadan sonra horseradish heroxidase ile konjuge edilmiş streptovisin (HRP) eklendi. Antikor bağlı AP-M30 miktarı ile orantılı olarak renk değişimi gözlendi. Renk değişimi gözlendikten sonra renk yoğunluğu ölçüldü.

\section{İstatistiksel analiz}

Veriler SPSS paket programıyla analiz edildi. Sürekli değişkenler ortalama \pm standart sapma ve kategorik değişkenler sayı ve yüzde olarak 
verildi. Parametrik test varsayımları sağlandığında bağımsız grup farklılıklarınkarş ılaştırılmasında İki Ortalama Arasındaki Farkın Önemlilik Testi; parametrik test varsayımları sağlanmadığında ise bağımsız grup farklılıkların karşılaştırılmasında Mann-Whitney $U$ testi kullanıldı. Bağımlı grup karşılaştırmalarında, parametrik test varsayımları sağlandığında İki eş arasındaki farkın önemlilik testi; parametrik test varsayımları sağlanmadığında ise Wilcoxon eşleştirilmiş iki örnek testi kullanıldı. Sürekli değişkenler arasındaki ilişkilerin incelenmesinde Spearman korelasyon katsayısı kullanıldı. <0,05'den küçük $p$ değerleri istatistiksel olarak anlamlı kabul edildi.

Sonuç olarak çalışmaya dahil edilen 63 hastadan lamivudin grubundan 2, tenofovir grubundan 1 olmak üzere toplam 3 hasta takibe gelmedikleri için çalışmadan çıkarıldı ve çalışma 60 hasta ile tamamlandı. Hastaların 34 'ü kadın $(\% 56,7)$ ve 26 'sı erkek $(\% 43,3)$ olup yaş ortalaması $46 \pm 10,7$ (yıl) idi.

Öncelikle çalışmaya alınan tüm hastalarda, tedavi başlangıcında saptanan AST, ALT, HBVDNA, HAI, fibrozis düzeyleri ile HbsAg ve M30 antijen düzeyleri arasındaki korelasyon ilişkisi değerlendirildi. Tedavi başlangıcında saptanan AST, ALT, HBVDNA düzeyleri ile HbsAg ve M30 antijen arasında pozitif korelasyon saptandı. HAI, Fibrozis dereceleri ile HbsAg arasında anlamlı ilişki saptanmazken, HAI, Fibrozis dereceleri ile M30 antijen düzeyleri arasında pozitif korelasyon saptandı (Tablo 1).

Tablo 1. Tüm hastalarda tedavi öncesi saptanan $\mathrm{HbsAg}$ ve M30 antijen düzeyleri ile AST, ALT, HBVDNA, HAI, fibrozis düzeyleri arasındaki korelasyon analizi

\begin{tabular}{lll}
\hline & $\begin{array}{l}\mathrm{HbsAg} \\
(\mathrm{IU} / \mathrm{L})\end{array}$ & $\begin{array}{l}\text { M30 } \\
(\mathrm{IU} / \mathrm{L})\end{array}$ \\
\hline AST $(\mathrm{IU} / \mathrm{ml})$ & $p<0,0001, \mathrm{r}: 0,533$ & $p<0,0001, \mathrm{r}: 0,590$ \\
$\mathrm{ALT}(\mathrm{IU} / \mathrm{ml})$ & $p<0,0001, \mathrm{r}: 0,503$ & $p<0,0001, \mathrm{r}: 0,491$ \\
$\mathrm{HBVDNA}(\mathrm{kopya} / \mathrm{ml})$ & $p<0,0001, \mathrm{r}: 0,831$ & $p<0,0001, \mathrm{r}: 0,522$ \\
$\mathrm{HAI}$ & $p>0,05, \mathrm{r}: 0,174$ & $p<0,0001, \mathrm{r}: 0,534$ \\
Fibrozis & $p>0,05, \mathrm{r}: 0,135$ & $p<0,01, \mathrm{r}: 0,374$ \\
HbsAg (IU/L) & & $p<0,01, \mathrm{r}: 0,411$ \\
\hline
\end{tabular}

Sonrasında tedavi verilen tüm hastalarda tedavinin başlangıcında ve tedavinin 6. ayında saptanan AST, ALT, HBVDNA, HbsAg ve M30 antijen düzeylerindeki düşüş karşılaştırıldı.
Tedavi verilen tüm hastalarda değerlendirilen tüm parametrelerde istatistiksel olarak anlamlı azalma olduğu görüldü (Tablo 2).

Tablo 2. Tüm hastalarda tedavi başlangıcı ve tedavinin 6. ayında saptanan AST, ALT, HBVDNA, HbsAg ve M30 düzeylerinin karşılaştırılması

\begin{tabular}{llll}
\hline & $\begin{array}{l}0 . \text { ay } \\
\text { Ortalama } \pm \text { std sapma }\end{array}$ & $\begin{array}{l}6 . \text { ay } \\
\text { Ortalama } \pm \text { std sapma }\end{array}$ & $p$ value \\
\hline AST (IU/ml) & $46,47 \pm 42,05$ & $24,43 \pm 7,86$ & $p<0,0001$ \\
ALT (IU/ml) & $57,47 \pm 73,28$ & $27,65 \pm 17,99$ & $p<0,0001$ \\
HBVDNA (Kopya/ & $12607824,03 \pm 27434892,28$ & $767,07 \pm 1607,81$ & $p<0,0001$ \\
ml) & $14855,9 \pm 3226,47$ & $11762,55 \pm 2709,78$ & $p<0,0001$ \\
HbsAg (IU/L) & $325,495 \pm 69,704$ & $261,507 \pm 40,243$ & $p<0,0001$ \\
\hline M30 antijen (IU/L) & & & \\
\hline
\end{tabular}


Hastalar lamivudin ve tenofovir tedavisi alanlar olarak iki gruba ayrıldı. Lamivudin ve Tenofovir grupları, tedavi sonunda AST, ALT, HBVDNA, HbsAg ve M30 antijen düzeylerindeki düşüş oranları açısından karşılaştrıldı ve iki grup arasında HBVDNA düzeylerindeki düşüş oranları açısından anlamlı fark saptanmadı. Bununla birlikte tedavi ile AST, ALT, HbsAg ve M30 antigen düzeylerindeki düşüş oranları tenofovir grubunda lamivudin grubuna göre istatistiksel olarak anlamlı düzeyde daha yüksek saptandı (Tablo 3).

Lamivudin ve tenofovir gruplarında tedavi başlangıcı ve tedavinin 6 . ayında $\mathrm{HbsAg}$ ve M30 antigen düzeylerinin düşüş eğrileri incelendiğinde tenofovir grubunda lamivudin grubuna göre her iki parametredeki düşüşünde istatistiksel olarak daha belirgin olduğu görüldü (Şekil 1, 2).

Tablo 3. Lamivudin ve tenofovir gruplarının, tedavi ile AST, ALT, HBVDNA, HbsAg ve M30 antijen düzeylerindeki düşüş oranları açısından karşılaştırılması

\begin{tabular}{llll}
\hline & $\begin{array}{l}\text { Lamivudin grubu (ortalama } \pm \\
\text { std sapma) }\end{array}$ & $\begin{array}{l}\text { Tenofovir grubu (ortalama } \pm \\
\text { std sapma) }\end{array}$ & $p$ değeri \\
\hline AST (IU/ml) & $0,18 \pm 46,78$ & $-41,14 \pm 37,74$ & $p<0,001$ \\
ALT (IU/ml) & $3,35 \pm 67,41$ & $-33,55 \pm 48,49$ & $p<0,05$ \\
HBVDNA (Kopya/ml) & $-98,23 \pm 6,96$ & $-99,37 \pm 3,25$ & $p>0,05$ \\
HbsAg (IU/L) & $-9,49 \pm 5,8$ & $-30,62 \pm 5,58$ & $p<0,001$ \\
M30 antijen (IU/L) & $-9,16 \pm 4,71$ & $-27,04 \pm 8,26$ & $p<0,001$ \\
\hline
\end{tabular}

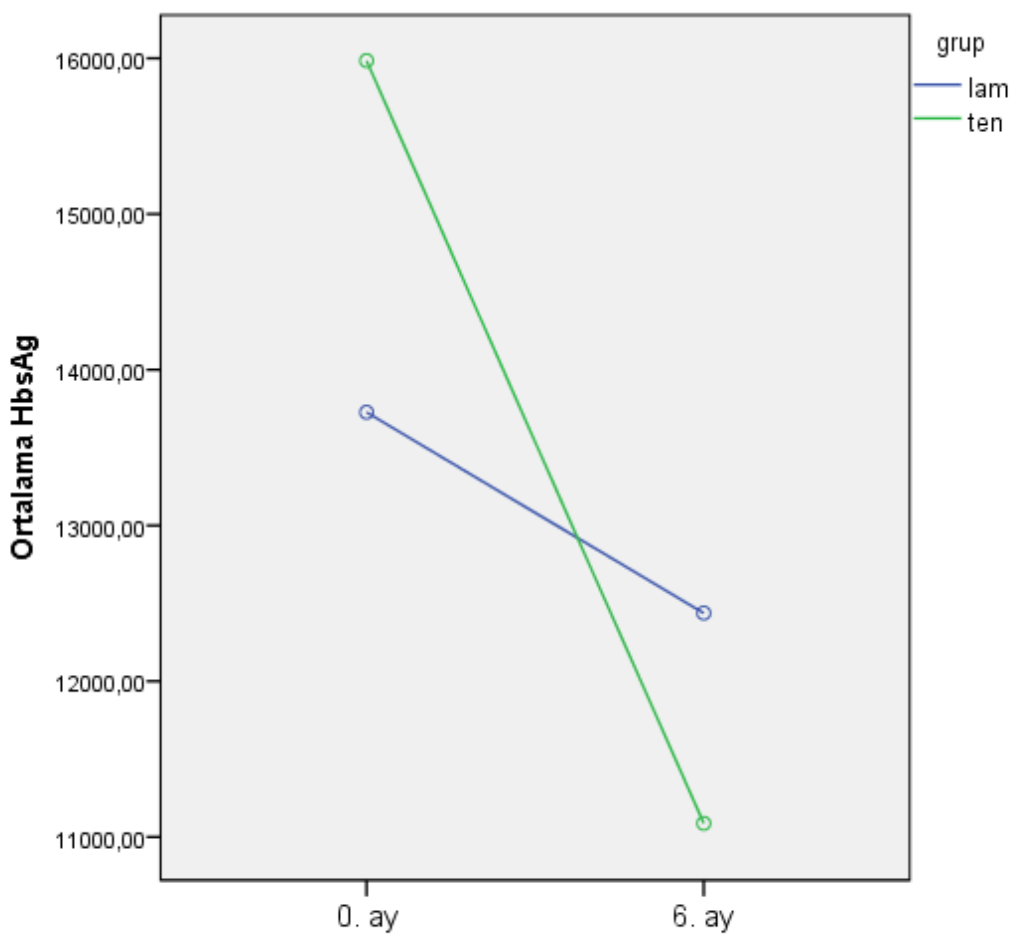

Şekil 1. Lamivudin ve tenofovir gruplarında tedavi ile $\mathrm{HbsAg}$ düzeylerinin düşüş eğrilerinin karşılaştırılması 


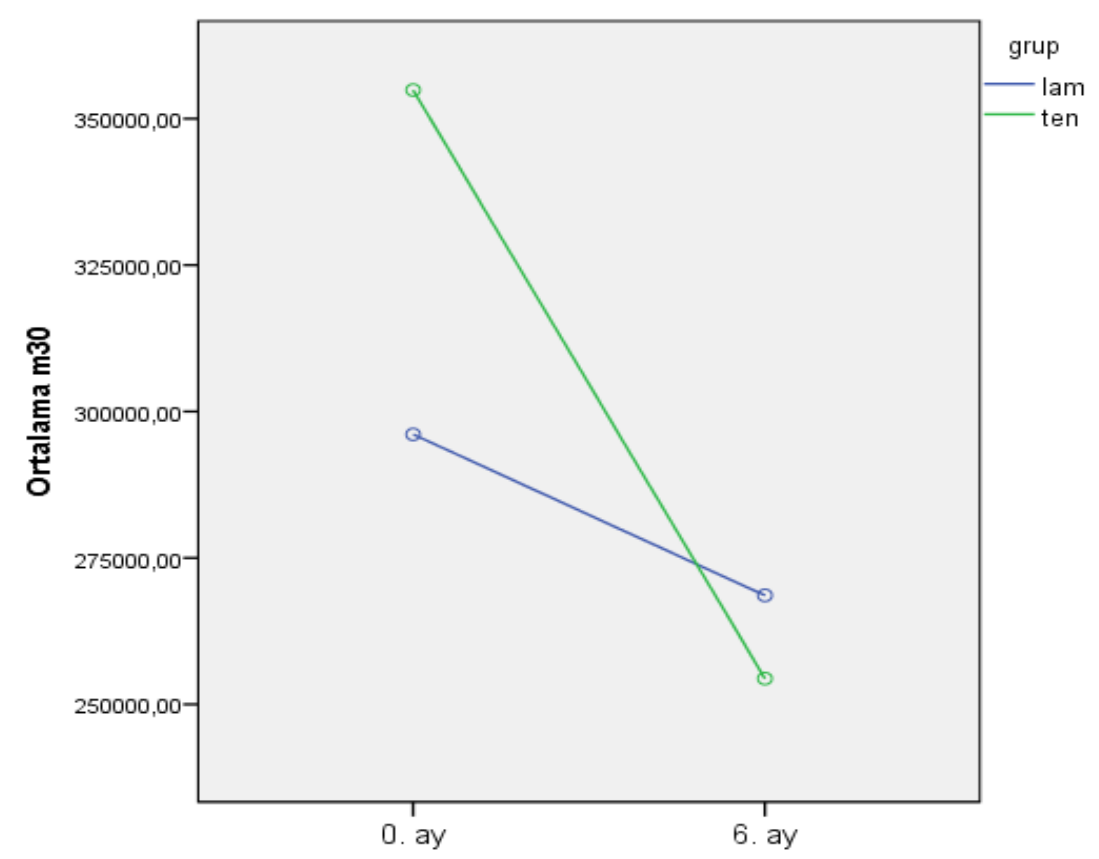

Şekil 2. Lamivudin ve tenofovir gruplarında tedavi ile $M 30$ antijen düzeylerinin düşüş eğrilerinin karşılaştırılması

\section{Tartışma}

Biz bu çalışmada kronik aktif hepatit B enfeksiyonunun şiddetinin tayini, ayrıca bu grupta oral antiviral ilaçların etkinliği ve tedavi takibinde HbsAg ve M30 antijen düzeylerininin faydalı birer marker olarak kullanılabileceğini göstermeyi amaçladık.

Kronik hepatit C, alkolik olmayan yağlı karaciğer hastalığı, KHB ve ilaca bağlı karaciğer hasarı ile ilgili çalışmalar, daha önce M30 antijen gibi hepatosit biyobelirteçlerinin hastalık şiddetini yansıtma, etiyolojileri ayırt etme ve prognoz bilgisi sağlama kabiliyetini bildirmiştir $[17,18,20,21]$. Kronik hepatit C'li hastalarda, M30 antijen düzeyleri ve fibrozis arasındaki ilişki defalarca bildirilmiştir [15, 22]. Cao ve ark.'nın [23] yapmış olduğu çalışmada ise kronik hepatit C enfeksiyonunda M30-CK18 serum konsantrasyonun transaminaz aktivitesinin yanı sıra inflamatuar aktivite ve karaciğer fibrozisi ile anlamlı ölçüde ilişkili olduğu gösterilmiştir. Parfieniuk Kowerda ve ark.'nın [24] yaptığı çalışmada HBV-DNA ve M30 antijen düzeyleri arasında pozitif korelasyon olduğu saptanmıştır. Bizim çalışmamızda aktif KHB enfeksiyonunda karaciğer biyopsisinde HAI ve fibrozis ile M30 antijen düzeyleri arasında istatistiksel olarak anlamlı ilişki olduğunu gösterdik. Bu hasta grubunda M30 antijen düzeyi ile AST ve ALT arasında da anlamlı düzeyde pozitif korelasyon olduğunu saptadık. Bu bize özellikle antihbe pozitif aktif KHB enfeksiyonu gibi seçilmiş bir hasta grubunda $\mathrm{M} 30$ antijen düzeyi ölçümünün karaciğer hasarını öngörmede oldukça faydalı olabileceğini düşündürdü. Bu sebeple M30 antijen düzeyinin KHB enfeksiyonunun aktivitesinin tayininde oldukça faydalı bir marker olabileceğini düşünüyoruz.

Günümüzde KHB tedavisinde lamivudin, telbivudin, adefovir gibi düşük direnç bariyeri olan oral antivirallerin yanında, tenofovir ve entekavir gibi yüksek direnç bariyerine sahip oral antiviraller kullanılmaktadır. NA tedavisinin amacı tedavi boyunca viral supresyonun sağlanmasıdır [25]. NA tedavisi ile HBV replikasyonunun uzun süreli supresyonunun karaciğer sirozu ve hepatoselüler karsinoma gelişme riskini azalttığı bilinmektedir [26, 27]. Bu sebeple bu hastaların tedavisinde mümkün olan en etkin seçeneğin kullanılması gerekmektedir. NA ile antiviral tedavi sırasında HBV kalıcılığının önemli bir mekanizması, enfekte hücrelerde cccDNA'nın kalıcılığıdır [8, 28]. Son çalışmalar antiviral tedavi öncesi ve sonrası HbsAg düzeyi ve cccDNA arasında anlamlı bir korelasyon olduğunu göstermiştir $[29,30]$. Bizim çalışmamızda da tedavi öncesi HbsAg ve HBVDNA düzeyleri arasında pozitif 
korelasyon saptadık. Ayrıca tedavi ile HbsAg ve HBVDNA düzeylerinde birbirine paralel, istatistiksel olarak belirgin düzeyde anlamlı düşüş saptadık. Bu bize bu hasta grubunda HbsAg düzeyi ölçümünün tedavi takibinde faydalı bir parametre olarak kullanılabileceğini düşündürdü.

İnflamatuar olaylar apoptoz ve nekroz olmak üzere bir cok mekanizma ile hepatosit ölümüne neden olur. KHB hastalarında antiviral tedavinin en önemli hedefi nekroinflamatuvar aktivitenin azalmasıdır ve NA tedavisi kronik hepatit B'li hastalarda apoptotik aktiviteyi azaltır. Ayrıca NA tedavisi ile M30 antijen ve ALT düzeylerinin birlikte azaldığı gösterilmiştir [31]. M30 antijeni, anti-viral tedaviyi takiben değiştirilebilir. $\mathrm{Bu}$, hem M30 antijeninin HBV-DNA'daki düşüşle eşzamanlı olarak azaldığını gösteren diğer çalışmalardan elde edilen bulgularla desteklenmektedir [31- 33]. Çalışmamızda NA tedavisi ile M30 antijen, AST, ALT HBVDNA düzeylerinde birbirine paralel olarak istatistiksel açıdan yüksek düzeyde anlamlı düşüş olduğunu gösterdik. Apoptozis markerı olan M30 ile nekrozun göstergesi olarak kabul edilen ALT düzeylerininin tedavi ile anlamlı düzeyde düşmesi ve HBVDNA da buna paralel düşüş olması bize M30 antijen düzeylerinin tedavi takibinde kullanılabileceğini düşündürdü. Bu sebeple M30 antijen düzeyi ölçümü hastalık şiddetini değerlendirmenin yanında tedavinin etkinliğinin değerlendirilmesi ve tedavi takibinde de kullanılabilecek bir markerdır.

Bizim çalışmamızda elde edilen ve literatüre katkı sağlayabilecek önemli sonuç ise şudur; HbsAg, AST, ALT, HbsAg ve M30 antijen düzeylerindeki düşüş, potent oral antiviral olan tenofovir alan hasta grubunda, lamivudin alan hasta grubuna göre daha belirgindi. Bu iki grup arasında HBVDNA düşüş oranında anlamlı fark saptanmamasına rağmen, tenofovir grubunda, lamivudin grubuna göre cccDNA nın indirek göstergesi olan $\mathrm{HbsAg}$ titresinde ve apoptozisin göstergesi olan M30 antijen titresinde belirgin düşüş olması oldukça anlamlı bir bulguydu. Maalesef günümüzde ülkemizde dahil, pek çok ülkede sosyoekonomik sebeplerden dolayı düşük direnç bariyeri olan oral antivirallerin kullanımına devam edilmektedir. Bu bilgi ışığında, günümüzde hala direnç bariyeri düşük olan oral antivirallerin ALT ve HBVDNA düzeyiyle takip edilerek kullanılmaya devam edilmesinin yanlış olduğunu düşünüyoruz.
Çıkar ilişkisi: Yazarlar çıkar ilişkisi olmadığını beyan eder.

\section{Kaynaklar}

1. Lavanchy D. Hepatitis B epidemiology, disease burden treatment and emerging prevention and control mesaures. J Viralhepat 2004;11:97-107. https://doi. org/10.1046/j.1365-2893.2003.00487.x

2. Liang TJ. Hepatitis $B$ : the virusand disease. Hepatology 2009;49:13-21. https://doi.org/10.1002/hep.22881

3. European Association for the Study of the Liver. EASL clinical practice guidelines: management of chronic hepatitis B. J Hepatol 2009;50:227-242. https://doi. org/10.1016/j.jhep.2008.10.001

4. Cornberg $\mathrm{M}$, Honer $\mathrm{Zu}$ Siederdissen C. HbsAg seroclearance with NUCs: rare but important. Gut 2014;63:1208-1209. https://doi.org/10.1136/ gutjnl-2013-306221

5. Brunetto MR. A new role for an old marker, HbsAg. J Hepatol 2010;52:475-477. https://doi.org/10.1016/j. jhep.2009.12.020

6. Sung JJ, Wong ML, Bowden S, et al. Intrahepatic hepatitis B virus covalently closed circular DNA can be a predictor of sustained response to therapy. Gastroentereology 2005;128:1890-1897. https://doi. org/10.1053/j.gastro.2005.03.009

7. Chan HL, Wong VW, Tse AM, et al. Serum hepatitis B surface antigen quantitatin can reflect hepatitis B virus in the liver and predict treatment response. Clin Gastroenterol Hepatol 2007;5:1462-1468. https://doi. org/10.1016/j.cgh.2007.09.005

8. Werle Lapostolle B, Bowden S, Locarnini S, et al. Persistence of cccDNA during the natural history of chronic hepatitis $B$ and decline during adefovir dipivoxil therapy. Gastroenterology 2004;126:1750-1758. https://doi.org/10.1053/j.gastro.2004.03.018

9. Manesis EK, Schina M, Le Gal F, et al. Quantitatvive analysis of hepatitis D virus RNA and hepatitis B surface antigen serum levels in chronic delta hepatitis improves treatment monitoring. Antivir Ther 2007;12:381-388.

10. Manesis EK, Hadziyannis ES, Angelopoulou OP, Hadziyannis SJ. Prediction of treatment-related HbsAg loss in $\mathrm{HBeAg}$ negative chronic hepatitis B: a clue from serum HbsAg levels. Antivir Ther 2007;12:73-82.

11. Fischer $R$, Baumert $T$, Blum HE. Hepatitis $C$ virus infection and apoptosis. World J Gastroenterol 2007;13:48654872. https://doi.org/10.3748/wjg.v13.i36.4865

12. Lapierre P, Beland K, Alvarez F. Pathogenesis of autoimmune hepatitis: from break of talerance to immunemediated hepatocyte apoptosis. Transl Res 2007;149: 107-113. https://doi.org/10.1016/j.trsl.2006.11.010

13. Day CP. Apoptosis in alcoholic hepatitis: a novel therapeutic target. J Hepatol 2001;34:330-333. https:// doi.org/10.1016/s0168-8278(00)00110-0 
14. McMahon BJ. The natural history of chronic hepatitis B virüs infection. Hepatology 2009;49:45-55. https://doi. org/10.1002/hep.22898

15. Kronenberger B, Zeuzem S, Sarrazin C, et al. Dynamics of apoptotic activity during antiviral treatment of patients with chronic hepatitis C. Antivir Ther 2007;12:779-787.

16. Kronenberger $B$, Wagner M, Hermann E, et al. Apoptotic cytokeratin 18 neoepitopes in serum of patients with chronic hepatitis C. J Viral Hepat 2005;12:307-314. https://doi.org/10.1111/j.1365-2893.2005.00594.x

17. Bantel H, Lugering A, Heidemann J, et al. Detection of apopitotic caspase activation in sera from patients with chronic $\mathrm{HCV}$ infection is associated with fibrotic liver injury. Hepatology 2004;40:1078-1087. https://doi. org/10.1002/hep.20411

18. Papatheodoridis GV, Hadziyannis E, Tsochatzis E, et al. Serum apoptotic caspase activity as a marker of severity in HBeAg-negative chronic hepatitis B virus infection. Gut 2008;57:500-506. https://doi. org/10.1136/gut.2007.123943

19. Lok ASF, McMohan BJ. American Assocation for the Study of Liver Diseases (AASLD). Chronic Hepatitis B: Update 2009 Hepatology 2009;50;661-662. https://doi. org/10.1002/hep.23190

20. Feldstein AE. Cytokeratin-18 fragment levels as noninvasive biomarkers for nonalcoholic steatohepatitis: a multicenter validation study. Hepatology 2009;50:1072-1078. https://doi. org/10.1002/hep.23050

21. Rutherford, A, King LY, Hynan LS, et al. Development of an accurate index for predicting outcomes of patients with acute liver failure. Gastroenterology 2012;143:1237-1243. https://doi.org/10.1053/j. gastro.2012.07.113

22. Jazwinski AB, Thompson AJ, Clark PJ, et al. Elevated serum CK18 levels in chronic hepatitis $C$ patients are associated with advanced fibrosis but not steatosis. J Viral Hepat 2012;19:278-282. https://doi.org/10.1111/ j.1365-2893.2011.01546.x

23. Cao Z, Li F, Xiang $X$, et al. Circulating cell death biomarker: good candidates of prognostic indicator for patients with hepatitis $B$ virus related acute-on chronic liver failure. Sci Rep 2015;18:5. https://doi.org/10.1038/ srep14240

24. Parfieniuk Kowerda A, Lapinski TW, Rogalska Plonska $M$, et al. Serum cytochrome $c$ and $m 30$-neoepitope of cytokeratin-18 in chronic hepatitis C. Liver International 2014;34:544-550. https://doi.org/10.1111/liv.12297

25. EASLclinical practice guidelines: management of chronic hepatitis B virus infection. J Hepatol 2012;57:167-185. https://doi.org/10.1016/j.jhep.2012.02.010

26. Colombo M. Does chemotherapy prevent HBVrelated hepatocellular carcinoma? Cons Dig Liver Dis 2010;42:298-301. https://doi.org/10.1016/S1590$8658(10) 60520-8$
27. Liaw YF. Impact of hepatitis B therapy on the long-term outcome of liver disease. Liver Int 2011;31:117-121. https://doi.org/10.1111/j.1478-3231.2010.02388.x

28. Takkenberg RB, Zaaijer HL, Molenkamp R, et al. Validation of a sensitive and specific real-time PCR for detection and quantitation of hepatitis $B$ virus covalently closed circular DNA in plasma of chronic hepatitis B patients. J Med Virol 2009;81:988-995. https://doi.org/10.1002/jmv.21477

29. Suh SJ, Bae SI, Kim JH, Kang K, Yeon JE, Byun KS. Clinical implications of the titer of serum hepatitis $B$ surface antigen during the natural history of hepatitis B virus infection. J Med Virol 2014;86:117-123. https:// doi.org/10.1002/jmv.23767

30. Park $\mathrm{H}$, Lee JM, Seo JH, et al. Predictive value of HbsAg quantification for determining the clinical course of genotype C HBeAg-negative carriers. Liver Int 2012;32:796-802. https://doi.org/10.1111/j.14783231.2011.02693.x

31. Farnika $\mathrm{H}$, Langea CM, Hofmanna WP, et al. Nucleos(t) ide analogue treatment reduces apoptotic activity in patients with chronic hepatitis B. Journal of Clinical Virology 2011;52:204-209. https://doi.org/10.1016/j. jcv.2011.08.009

32. Jochum, C, Gieseler RK, Gawlista I, et al. Hepatitis B-associated acute liver failure: immediate treatment with entecavir inhibits hepatitis $B$ virüs replication and potentially its sequelae. Digestion 2009;80:235-240. https://doi.org/10.1159/000236009

33. Giannousis IP, Manolakopoulos SG, Hadziyannis E, Georgiou A, Papatheodoridis GV. Changes of serum levels of keratin-18 fragments in hepatitis $B$ e antigennegative chronic hepatitis $B$ patients under oral antiviral therapy. Antiviral Therapy 2011;16:505-514. https://doi. org/ 10.3851/IMP1775

Etik kurul onayı: Pamukkale Üniversitesi Tıp Fakültesi Girişimsel Olmayan Klinik Araştırma Etik Komitesi tarafından 03/09/2015 tarih ve 15 sayı ile onaylanmıştır.

\section{Yazarların makaleye olan katkıları}

Z.D.Ö. ve M.Ç. çalışmanın ana fikrini ve hipotezini kurgulamış/kurgulamışlardır. Z.D.Ö. teoriyi geliştirmiş ve gereç ve yöntem bölümünü düzenlemiş/düzenlemişlerdir. Sonuçlar kısmınındaki verilerin değerlendirmesini İ.H.A. ve Y.G. yapmış/yapmışlardır. Makalenin tartışma bölümü Z.D.Ö. tarafından yazılmış, H.Y. ve M.Y. gözden geçirip gerekli düzeltmeleri yapmış ve onaylamıştır. Ayrıca tüm yazarlar çalışmanın tamamını tartışmış ve son halini onaylamıştır. 